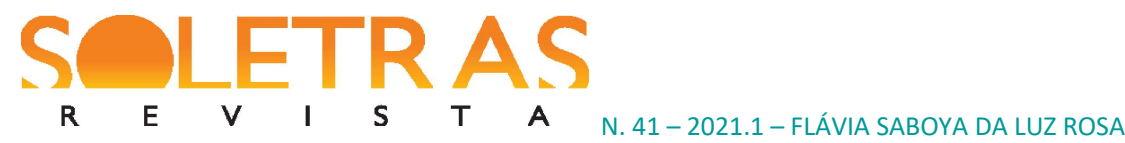

\title{
A metáfora conceptual como fator relevante para mudanças construcionais: um olhar sobre as microconstruções alto lá e toma lá dá cá
}

\author{
Flávia Saboya da Luz Rosa ${ }^{1}$
}

\begin{abstract}
Resumo: No presente artigo, objetiva-se traçar relações de duas metáforas conceptuais reconhecidas nos estudos cognitivistas, DISCUSSÃO É GUERRA e DISCUSSÃO DEFINE UM CAMINHO, com os processos que resultam em mudanças construcionais das microconstruções alto lá e toma lá dá cá. A pesquisa fundamenta-se na Linguística Cognitivo-Funcional (TOMASELLO, 1998) ou Linguística Funcional Centrada no Uso (adaptação de BYBEE, 2010). Este trabalho tem como base, sobretudo, a abordagem construcionalista de Traugott e Trousdale (2013) compatibilizada aos estudos sobre metáfora conceptual de Lakoff e Johnson (2003). Para a investigação pancrônica de alto lá (ROSA, 2019) valemo-nos do Corpus do Português e Corpus Tycho Brahe (século XIII ao XX), Diário do Congresso Nacional (séculos XX e XXI) e publicações contemporâneas da Web. Para o estudo sincrônico de toma lá dá cá (recorte de projeto em estágio inicial) foram coletados textos de 2000 a 2020 com uso da pesquisa avançada do Google. Por meio das análises dos contextos de mudança das microconstruções em foco, verifica-se o surgimento de novos conteúdos semânticos associados a conceptualizações socioculturalmente compartilhadas. Conclui-se, portanto, que a metáfora conceptual pode ser parte importante, junto a outros fatores tais como os históricos e os estruturais, nos processos de mudança e estabelecimento de construções linguísticas.
\end{abstract}

Palavras-chave: Metáfora conceptual. Mudança construcional. Construção. Funcionalismo. Cognitivismo.

\section{Introdução}

No que se refere a estudos linguísticos recentes, conforme apontam Martelotta e Alonso (2012), a tendência adotada por alguns pesquisadores, tanto brasileiros como estrangeiros, tem sido unir propostas do funcionalismo com algumas tradições teóricas da linguística cognitiva. Tal tendência tem sido chamada de Linguística Cognitivo-Funcional (TOMASELLO, 1998, 2003) ou Linguística Baseada no Uso (BYBEE, 2010). Esta última nomenclatura, de acordo com a autora, é, em certo sentido, um novo nome para o funcionalismo norte-americano, ao qual foi incorporada a abordagem construcionalista ${ }^{2}$,

\footnotetext{
${ }^{1}$ Mestre (2012) e Doutora (2019) em Estudos de Linguagem pela Universidade Federal Fluminense. Atua como pesquisadora na linha Teoria e Análise Linguística junto ao Grupo de Estudos Discurso \& Gramática - D\&G UFF. Rio de Janeiro, Brasil. E-mail: flaviasaboya@gmail.com. ORCID iD: 0000-0001-6149-265X

${ }^{2}$ Traugott e Trousdale (2013) empregam indistintamente os adjetivos "constructional" e "constructionalist" para se referirem à abordagem tratada na obra. Muitos pesquisadores brasileiros optam pela tradução construcional, e há quem adote o termo construcionista. Aqui, preferimos a nomenclatura construcionalista pelas seguintes razões: 1) construcional parece mais caracterizar o que se configura por meio de ou se refere diretamente a construções do que apontar para a concepção teórica propriamente dita; 2) construcionista é o termo consagrado para referir-se à teoria educacional fundada por Seymour Papert, o construcionismo; 3) construcionalista, por
} 
procedente do cognitivismo. A comunidade de pesquisadores funcionalistas no Brasil, a começar pelo Grupo de Estudos Discurso \& Gramática (D\&G) ${ }^{3}$, optaram por adaptar e acrescentar o termo funcional à denominação proposta por Bybee, adotando a expressão Linguística Funcional Centrada no Uso (LFCU).

No presente artigo, apresentamos ainda a compatibilização da abordagem construcionalista, sobretudo baseada em Traugott e Trousdale (2013), com a teoria da metáfora conceptual, fundamentada em Lakoff e Johnson (2003). A partir dos estudos das trajetórias de mudança das microconstruções alto lá e toma lá dá cá, temos verificado que o compartilhamento sociocultural de algumas metáforas conceptuais favorecem mudanças construcionais cujos resultados apresentam conteúdo aplicado ao âmbito discursivo. No que tange à análise das mudanças construcionais da microconstrução alto lá, classificada em Rosa (2019) como marcador discursivo refreador-argumentativo, verificamos a atuação de fatores históricos, estruturais e cognitivos. Em especial, consideramos o compartilhamento da metáfora conceptual DISCUSSÃO É GUERRA como fator integrante desse processo de mudança. Concernente à análise das mudanças construcionais da microconstrução toma lá dá cá, que representa uma das instanciações da construção de correlação locativa ${ }^{4}$, concluímos que a partilha sociocultural da metáfora conceptual DISCUSSÃO DEFINE UM CAMINHO 5 integra e favorece o processo de mudança.

Os dados analisados para investigação pancrônica da microconstrução alto lá são provenientes dos seguintes corpora: Corpus do Português e Corpus Tycho Brahe (textos do século XIII ao XX), Diário do Congresso Nacional (transcrições de debates parlamentares dos séculos XX e XXI), além de algumas publicações contemporâneas de sites da Web. Por se tratar de estágio de desenvolvimento inicial da pesquisa sobre a microconstrução toma lá dá cá, o corpus utilizado representa um recorte sincrônico formado por textos produzidos nas duas últimas décadas, coletados por meio da ferramenta de pesquisa avançada do Google. É importante mencionar que preservamos a grafia dos construtos do modo exato como constava

analogia às perspectivas funcionalista, cognitivista, gerativista etc., apresenta um sufixo que, tradicionalmente, remete a fundamentações teóricas.

${ }^{3} \mathrm{O} D \& G$ é um grupo de estudos e pesquisas interinstitucional, com sedes na UFF, UFRJ e UFRN.

${ }^{4} \mathrm{O}$ projeto, ainda em desenvolvimento, que trata das construções de correlação locativa, será abordado na seção de análise de dados.

${ }^{5}$ Embora não esteja no formato canônico DOMÍNIO ALVO É DOMÍNIO FONTE, a metáfora em questão foi mencionada por Lakoff e Johnson (2003) como uma das implicações da metáfora DISCUSSÃO É UMA VIAGEM. Outra tradução possível, num formato mais convencional, em que se mantém o verbo ser, seria DISCUTIR É PERCORRER UM CAMINHO. 


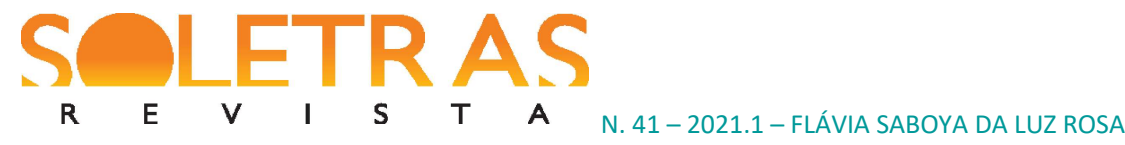

nos dados. Sendo assim, nos exemplos, aparecerão estruturas como toma-lá-dá-cá (grafada com hífen) e toma lá, dá cá (grafada com vírgula). No texto principal, no entanto, optamos por manter a forma apresentada no Vocabulário Ortográfico da Língua Portuguesa (VOLP) ${ }^{6}$. Neste artigo, por conta de o foco temático representar uma fração de pesquisas maiores, optamos por realizar análises exclusivamente qualitativas.

Para dar conta da proposta deste trabalho, apresentamos três seções: i) Fundamentação teórica, subdividida em três subseções: Construção, Mudança construcional e construcionalização e Metáfora conceptual; ii) Análise de dados, subdividida em duas subseções: A microconstrução alto lá e A microconstrução toma lá dá cá e iii) Considerações finais.

\section{Fundamentação teórica}

Com base, principalmente, na abordagem de Traugott e Trousdale (2013), apresentamos os conceitos dos termos construção, mudança construcional $\mathrm{e}$ construcionalização. Fundamentados nos postulados, sobretudo, de Lakoff e Johnson (2003), expomos o que se entende por metáfora conceptual.

\section{Construção}

Na visão de Traugott e Trousdale (2013) e de vários pesquisadores cognitivistas, como Goldberg (2006) e Langacker (2008), em um modelo construcionalista, a língua é composta por pareamentos forma-conteúdo ${ }^{7}$, também chamados de construções, organizados em rede.

Sendo assim, entendemos que as expressões em foco nesta pesquisa passam a ser empregadas como unidades simbólicas convencionais. As construções são unidades no sentido de que o signo é arraigado como um pareamento forma-conteúdo na mente do usuário

\footnotetext{
${ }^{6}$ Disponível em: https://www.academia.org.br/nossa-lingua/busca-no-vocabulario. Acesso em: 20 nov. 2020.

7 Traugott e Trousdale (2013) utilizam a expressão "form-meaning pairings", que tem sido traduzida por pareamentos forma-significado. Há ainda quem defenda a ideia de forma-função ou forma-sentido. Neste trabalho, optamos pelo par forma-conteúdo, por considerarmos o termo mais abrangente e possibilitar especificações referentes à função, significado e sentido, a partir da proposta de Oliveira e Arena (2019).
} 


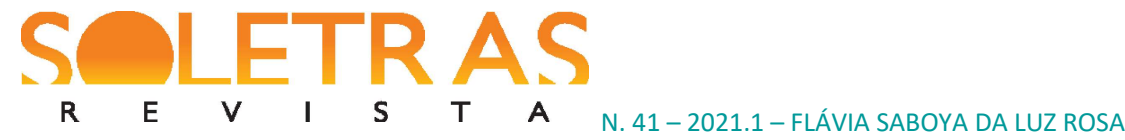

da língua, devido a aspectos de forte idiossincrasia ou grande frequência. Elas são simbólicas, pois são signos, associações entre forma e conteúdo. E são convencionais, por serem compartilhadas por um grupo de falantes.

Dos modelos de gramática descritos por Traugott e Trousdale (2013), interessa-nos, em particular, o enquadre apontado na Radical Construction Grammar, em que Croft (2001) faz a representação para a estrutura simbólica de uma construção, mostrando a relação, por nós adaptada, entre forma (propriedades sintáticas, morfológicas e fonológicas) e conteúdo (propriedades semânticas, pragmáticas e discursivas)

Traugott e Trousdale (2013) apresentam três critérios bastante relevantes para análise da arquitetura das construções: esquematicidade, produtividade e composicionalidade. A esquematicidade é a propriedade de categorização que envolve necessariamente abstração. Adaptando a proposta de Oliveira e Arena (2019) e compatibilizando-a com as definições de Traugott (2008), apresentamos a terminologia, aqui adotada, referente ao pareamento formaconteúdo para os dois níveis mais baixos da hierarquia construcional: i) microconstrução (estrutura específica-significado) e ii) construto (estrutura substancial-sentido). A microconstrução representa uma virtualidade e o construto, o uso efetivo.

O segundo fator considerado importante para a análise construcional é a produtividade. Bybee (2003) distingue frequência type (o número de diferentes expressões apresentadas por um padrão particular) e frequência token (o número de vezes que a mesma unidade ocorre no texto).

O terceiro fator de grande relevância no estudo de construções é a composicionalidade, que diz respeito à transparência entre forma e conteúdo. Do ponto de vista construcionalista, a composicionalidade é pensada em termos de correspondência ou incompatibilidade entre aspectos da forma e aspectos do conteúdo. Se um construto é semanticamente composicional, o entendimento do significado de cada item individual decodifica o significado do todo. Porém, se o construto não é composicional, haverá divergência entre o significado dos elementos individuais e o significado do todo. Contudo, trata-se de um parâmetro gradiente e, portanto, os construtos podem ser classificados como mais ou menos composicionais. 


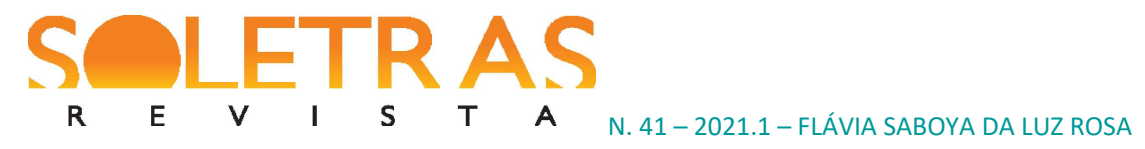

\section{Mudança construcional e construcionalização}

Para analisar as transformações linguísticas sofridas pelas microconstruções em foco, devemos levar em conta os dois principais tipos de mudanças apontados por Traugott e Trousdale (2013): mudança construcional e construcionalização.

A mudança construcional é a mudança que afeta uma das dimensões internas de uma construção já existente, sem que ocorra a criação de nova construção. A alteração pode ser referente às propriedades da forma (sintática, morfológica, fonológica) ou relacionada às propriedades do conteúdo (semântico, pragmático, discursivo). A construcionalização costuma ser precedida e sucedida por mudanças construcionais, isto é, por uma sucessão de passos incrementais convencionalizados.

A construcionalização é a criação de uma associação formanova-conteúdonovo, ou seja, é o desenvolvimento de uma nova unidade ou signo. A construcionalização forma novos tipos de nós com alteração morfológica, sintática ou fonológica e alteração de conteúdo semântico, pragmático ou discursivo, codificado na rede linguística de uma população de falantes. De modo geral, é acompanhada de mudanças referentes à esquematicidade, produtividade e composicionalidade. A construcionalização envolve, minimamente, neoanálise de uma das propriedades da forma e de uma das propriedades do conteúdo construcional. Mudanças somente formais e mudanças somente de conteúdo não constituem construcionalização, tratando-se, sim, de mudanças construcionais. Traugott e Trousdale (2013) focam em dois tipos principais de construcionalização: a gramatical e a lexical. A construcionalização gramatical é o desenvolvimento, por meio de uma série de mudanças em micropassos, de um pareamento de formanova-conteúdonovo que apresenta função principalmente procedural/gramatical. A construcionalização lexical é o desenvolvimento de um pareamento de formanova-conteúdonovo que, no continuum $^{8}$, está mais relacionado ao polo lexical, isto é, que faz referência a entidades/eventos do mundo biossocial.

\footnotetext{
${ }^{8}$ A gramática de construções não apresenta divisão limítrofe entre expressões lexicais e gramaticais, e a abordagem construcionalista amplia as formas de se pensar na transição de expressões que vão do mais lexical ao mais gramatical. Trabalha-se, então, com a ideia de continuum, isto é, um número infinito de gradações de um extremo a outro.
} 


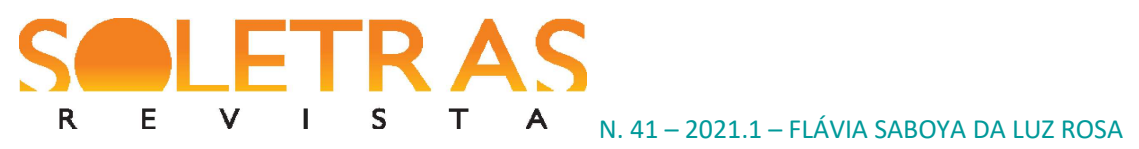

\section{Metáfora conceptual}

Segundo Lakoff (2006), nas teorias clássicas, a metáfora era exclusivamente relacionada à linguagem e não ao pensamento. O termo metáfora era definido como uma expressão linguística nova ou poética em que uma ou mais palavras utilizadas para apontar determinado conceito são empregadas diferentemente de seu significado convencional e usual para manifestar um conceito "similar". Contudo, os questionamentos sobre as generalizações que determinavam essas expressões linguísticas, classicamente chamadas de "metáforas poéticas", levaram à compreensão de que o locus de tais generalizações não era a linguagem, e sim o pensamento.

De acordo com o autor, no pensamento, ocorrem mapeamentos entre domínios conceptuais, aplicados não só a novas expressões poéticas como também a muitas expressões da linguagem comum do dia a dia. Logo, a teoria geral da metáfora se dá pela caracterização desses mapeamentos mencionados, isto é, pela conceptualização de um domínio mental em termos de outro. Nesse processo, conceitos abstratos do cotidiano, como tempo, estado, mudança, intenção etc., também passam a ser metafóricos. A conclusão a que se chega é que a metáfora é absolutamente central à semântica da língua usual, e o estudo da metáfora literária é uma extensão do estudo da metáfora cotidiana. Esta é caracterizada por um enorme sistema de milhares de mapeamentos entre domínios, e esse sistema é usado na produção de novas metáforas. A esse respeito, Lakoff e Johnson (2003) declaram: "a metáfora faz parte da vida cotidiana, não somente na linguagem, como também no pensamento e na ação. Nosso sistema conceitual, a partir do qual pensamos e agimos, é fundamentalmente metafórico pela sua própria natureza". (LAKOFF; JOHNSON, 2003, p. 4).

A partir do que foi exposto, levando em conta a carga histórica que a palavra metáfora ainda encerra, optamos por utilizar o termo metáfora conceptual para indicarmos o mapeamento entre domínios no sistema conceptual. Já o termo expressão metafórica é aqui utilizado para nos referirmos a uma expressão linguística - sejam palavras, sintagmas ou sentenças - que é a realização patente do mapeamento entre domínios.

A teoria contemporânea de que a metáfora é principalmente conceptual, convencional e parte do sistema ordinário do pensamento e da linguagem também pode ser encontrada no ensaio de Reddy (1993). Em sua obra, o autor mostra que a metáfora é componente importante e indispensável do modo rotineiro de conceituar o mundo, e que o nosso 


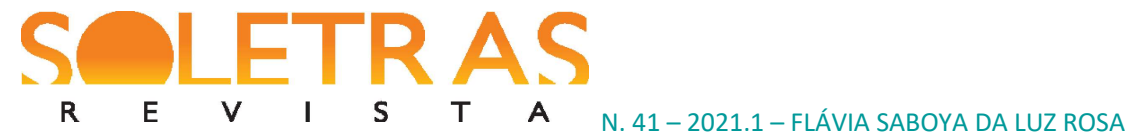

comportamento cotidiano reflete a nossa compreensão metafórica da experiência. Embora outros teóricos tenham tratado do assunto, Reddy foi o primeiro a demonstrá-lo por meio de rigorosas análises linguísticas, estabelecendo generalizações sobre diversos exemplos. Seu capítulo sobre o conceito de comunicação por metáfora impulsionou e direcionou um ramo inteiro da linguística e da ciência cognitiva para os estudos dos sistemas de pensamento metafórico que usamos para raciocinar e basear nossas ações, e que constituem grande parte da estrutura da linguagem.

Nos anos sucessivos ao trabalho de Reddy (1993), um enorme sistema de metáforas conceptuais, rotineiras e convencionais, foi sendo descoberto. Trata-se de um sistema que estrutura nossa conceptualização do dia a dia, incluindo a maioria dos conceitos abstratos, e que está por trás de muitas expressões da linguagem cotidiana. Essa evidenciação fez cair por terra os equívocos a respeito do literal e do figurado. Assim como Lakoff (2006), e diferentemente das antigas suposições sobre a suficiência desse tipo de linguagem, assumimos como literal $^{9}$ a ideia que não é compreendida por meio de metáfora. Muitos conceitos comuns podem receber tratamento metafórico ou literal. Porém, quanto mais distante da experiência física concreta e mais próximo de referências abstratas for o tema, maior será a probabilidade de conceptualização metafórica. $\mathrm{O}$ autor chega a afirmar que, em se tratando de abstrações e emoções, a aplicação metafórica é regra. Lakoff (2006) nos apresenta cinco tipos de evidência para a existência de um sistema de metáforas conceptuais convencionais: i) Generalizações determinam polissemia, isto é, multiplicidade de significados relacionados a uma palavra; ii) Generalizações determinam padrões de inferência, isto é, casos em que um padrão de inferências de um domínio conceptual é usado em outro domínio; iii) Generalizações determinam novas expressões metafóricas (LAKOFF; TURNER, 1989); iv) Generalizações determinam padrões de mudança semântica (SWEETSER, 1990); v) Experimentos psicolinguísticos atestam a existência de um sistema de metáforas conceptuais convencionais (GIBBS, 1990).

Conforme explicam Lakoff e Johnson (2003), a conceptualização está fortemente atrelada às questões culturais:

\footnotetext{
9 Atualmente, não tem sido raro escutar de falantes do português brasileiro a palavra literalmente com um sentido exclusivamente enfático, sem a oposição ao uso de um conceito de modo metafórico. Nesses casos, o maior estranhamento, ao menos por parte dos mais atentos a etimologias, ocorre justamente quando se emprega o termo anteposto ou posposto a uma expressão metafórica. Exemplo de fala de uma Técnica em Ensino a Distância, do Rio de Janeiro, sobre a dificuldade de marcar reuniões com professores em 2015: "Eu tive que, literalmente, laçar o professor no restaurante".
} 


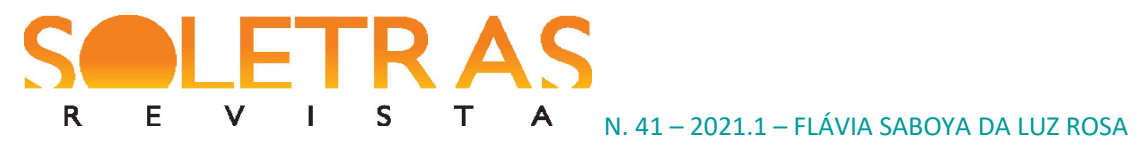

cada cultura deve definir uma realidade social em que as pessoas têm papéis que façam sentido para elas e em termos dos quais possam funcionar socialmente. Não surpreendentemente, a realidade social definida por uma cultura afeta sua concepção da realidade física. O que é real para um indivíduo como membro de uma cultura é um produto tanto de sua realidade social quanto da maneira como isso molda sua experiência do mundo físico. Visto que grande parte de nossa realidade social é entendida em termos metafóricos, e visto que nossa concepção do mundo físico é parcialmente metafórica, a metáfora desempenha um papel muito significativo na determinação do que é real para nós. (LAKOFF; JOHNSON, 2003, p. 147. Tradução nossa).

Nesse sentido, há o entendimento de que as experiências são elaboradas cognitivamente a partir de outras já existentes, havendo, assim, a projeção de uma experiência já incorporada e linguisticamente determinada a outra que deverá ser mapeada pelo pensamento e pela linguagem. No entanto, nosso sistema conceptual, normalmente, não é percebido num processo consciente e, na maioria das vezes, os pensamentos e ações ocorrem de forma quase automática, sem nos darmos conta de que há certas diretrizes de conduta por trás deles.

A linguagem, então, de acordo com Vereza (2012, p. 52-53) "desempenha um papel determinante na reificação da metáfora” estabelecendo uma relação direta entre pensamento, linguagem e realidade. “Assim, a linguagem, e não só o pensamento, é objeto de análise dentro da teoria de Lakoff e Johnson (2003), uma vez que apresenta marcas - explícitas ou não - das metáforas que a constituem". Os exemplos de expressões linguísticas licenciadas pelas metáforas conceptuais DISCUSSÃO É GUERRA e DISCUSSÃO DEFINE UM CAMINHO serão analisados na seção seguinte.

\section{Análise de dados}

Nesta seção, procede-se à verificação de alguns fatores, tais como os históricos, estruturais e cognitivos, nos processos de mudança construcional da microconstrução alto lá e da microconstrução toma lá dá cá. No que se refere aos processamentos cognitivos, é 


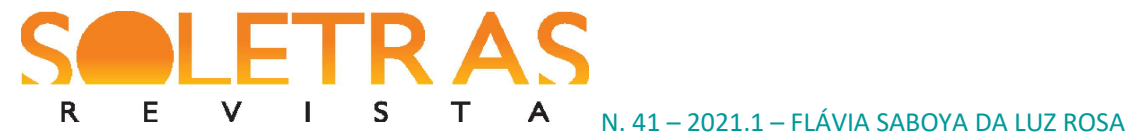

analisada a relevância das metáforas conceptuais DISCUSSÃO É GUERRA e DISCUSSÃO DEFINE UM CAMINHO como fatores favorecedores da mudança e do estabelecimento das construções em foco na língua portuguesa. As análises são apresentadas em duas subseções: A microconstrução alto lá e A microconstrução toma lá dá cá.

\section{A microconstrução alto lá}

Para que se entenda a origem, a composição e o emprego da microconstrução alto lá, faz-se necessária, primeiramente, a compreensão do significado do elemento alto, um comando utilizado em exercícios e combates de infantaria. Considerando uma das descrições de Bluteau (1728) sobre o termo e as explicações encontradas em Nascentes (1955) e Cunha (1997), concluímos tratar-se de adaptação em português da forma halt, correspondente ao imperativo do verbo alemão halten (parar), empregado para cessar a marcha da tropa.

\section{Conjuntura histórica}

Tendo em vista que o termo é detectado nos corpora, na acepção anteriormente apresentada, a partir do século XVII, fazemos um breve comentário acerca do universo militar português durante a Idade Moderna. É importante destacar que as ações de guerra lusitanas, devido ao lançamento e manutenção do império no Brasil, causaram impacto de diversas naturezas na região, inclusive cultural e linguístico.

Segundo o historiador e professor da Universidade de Coimbra Rui Bebiano (1999), entre os séculos XVI e XVIII, Portugal foi fortemente marcado pela dedicação a constantes batalhas. Em se tratando da questão cultural, Bebiano declara que, ao longo desses três séculos, houve uma profusão literária em torno do tema. Tal bibliografia versava sobre o direito da guerra, a memória dos fatos marciais, a forma de dirigir operações, de treinar as tropas ou de construir mecanismos ofensivos e defensivos. $\mathrm{O}$ investigador de história afirma que, no extenso sermonário ${ }^{10}$ de temática guerreira, difundido ao longo do século XVII, os fragmentos memorialistas, a poesia e a literatura de cordel testemunham a intensão de situar a guerra como manifestação atrelada ao centro da vida e às preocupações dos portugueses da época.

${ }^{10}$ Segundo Bebiano (1999), os sermões de temática guerreira foram difundidos sobretudo por Antônio Vieira. Não por acaso, encontramos, no texto do jesuíta, um dos primeiros registros da expressão fazer alto. 


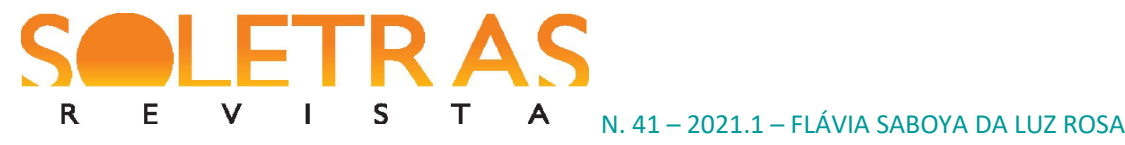

A partir do exposto, vislumbram-se os caminhos pelos quais alguns termos, inicialmente circunscritos às situações de treinamento e prática de guerra, tenham se descentralizado, passando a ser empregados em contextos mais variados, como é o caso de alto.

\section{Trajetória de mudanças}

A partir da assunção de que o uso do termo na língua portuguesa iniciou-se em âmbito militar com o sentido de realização de parada da marcha da tropa, é possível analisar os fragmentos de texto dos corpora, com base na abordagem de Diewald $(2002,2006)$ sobre os tipos de contexto de mudança: atípico, crítico, isolado.

(1) Quando dá a voz de fogo é sempre contra o palácio! Apertou-me com mais violência a mão, e, colocando a sua boca muito perto do meu ouvido, murmurou: - A mim ninguém me tira da cabeça que é o do Cercal! E, afastando-se, olhou-me fixamente para melhor descobrir o efeito da confidência. Nisto, do fundo do largo, elevou-se uma voz aguda e estridente, gritando: - Às armas! Era o João da tropa. Marchou em passo acelerado até defronte do palácio, onde estacou à voz de - alto! - Depois, com grandes gestos, ia executando sucessivamente as vozes que berrava - carregar! apontar! fogo! Vestido com uma velha fardeta de soldado, esfrangalhada e a cair aos farrapos, com uma calça remendada listrada de trapos vermelhos e com um chapéu armado de papel na cabeça, segurava na mão uma cana, trazendo outra mais pequena pendente da cinta à laia de baioneta. Com a sua comprida barba e o olhar incerto de doido, tinha um ar estranhamente fantástico! (Corpus do Português: O segredo da minha cadeirinha, de Conde de Arnoso, 1886).

- Contexto fonte

No exemplo (1), anteriormente apresentado, merece destaque o seguinte trecho: "Nisto, do fundo do largo, elevou-se uma voz aguda e estridente, gritando: - Às armas! Era o João da tropa. Marchou em passo acelerado até defronte do palácio, onde estacou à voz de alto! - Depois, com grandes gestos, ia executando sucessivamente as vozes que berrava carregar! apontar! fogo!”. Nesse fragmento, verificamos o uso de alto em contexto fonte, isto é, em âmbito militar, exprimindo o sentido de comandar a interrupção da marcha da tropa. É importante ter ciência de que o vocábulo alto foi importado do léxico alemão e introduzido na língua portuguesa expressando esse sentido específico. Sendo assim, a expansão semântica do termo que passa a abranger a interrupção de outras atividades, em conjunturas diferentes 


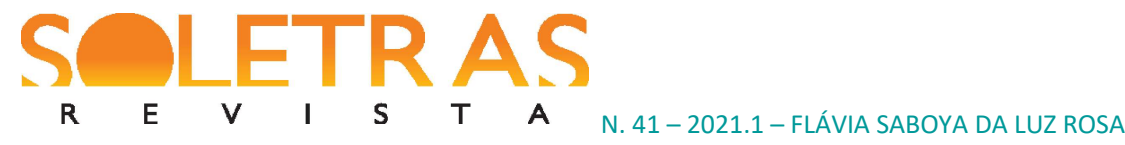

daquelas em que se inserem as práticas de guerra, deve ser avaliada como fenômeno do contexto atípico, conforme consta no próximo tópico.

\section{- Contexto atípico}

Diewald $(2002,2006)$ declara que a unidade linguística mostra uma expansão inespecífica de sua distribuição nos contextos em que não havia sido usada anteriormente, isto é, em contextos atípicos. Ainda acrescenta que, nesses contextos, faz-se uso de expressões existentes que - por meio de implicaturas conversacionais - aparecem em combinações incomuns e, ao mesmo tempo, podem ser facilmente interpretadas devido à estrutura composicional $^{11}$ dessas formas. Vejamos o exemplo a seguir:

(2) Nada... nada de reflexões, continuou sorrindo-se; mãe Sara (permita que lhe chame assim), dê-me uma xícara do seu café e metade do seu pão... eu já estou bom... completamente bom... e sinto uma fome terrível... ah... então parece que duvidam... pois, meus bons amigos, eu não faço cerimônia... com licença. E dizendo isto o moço serviu-se de café e pão, e começou a fazer boa companhia aos seus hóspedes; já se dispunha a repetir segunda dose de café, quando a velha o suspendeu. - Alto lá, senhor! Não se come tanto de uma vez ao entrar em convalescença.. - Também acholhe razão, mãe Sara, e sujeito-me agora a suas determinações; porém, ali pelo correr das duas horas há de fazer-me o favor de servir-me com uma... está bem, não vamos tão depressa; com metade de uma galinha ensopada, guisada, assada, ou como the parecer. É certo que agora não tenho dinheiro, porém amanhã, mãe Sara, eu lhe prometo que há de ser paga [...]. (Corpus do Português: $O$ moço loiro, de Joaquim Manuel de Macedo, 1845).

Em (2), observamos que o termo alto, que aparece vinculado ao afixoide ${ }^{12}$ lá, é empregado em âmbito civil, num episódio em que pessoas tomam café da manhã num determinado estabelecimento. O protagonista da cena, que já havia se servido de café e pão, é interrompido ao tentar repetir a dose da bebida: "Alto lá, senhor! Não se come tanto de uma vez ao entrar em convalescença". Visto que se trata de um contexto diferente do original, o consideramos contexto atípico.

No fragmento, constatamos o uso da expressão já existente, alto, em combinação incomum, alto lá, quando comparada ao contexto fonte. Apesar do surgimento da nova forma,

\footnotetext{
${ }^{11}$ Entendemos que, nesse estágio, o construto deva apresentar alguma medida de composicionalidade, mas não necessariamente composicionalidade total.

${ }_{12}$ Advérbio locativo que constitui subparte periférica de construções mais complexas (cf. BOOIJ, 2013), como ocorre, por exemplo, em calma lá (cf. ROSA, 2019), e não mais aponta para uma referência espacial no mundo biossocial.
} 


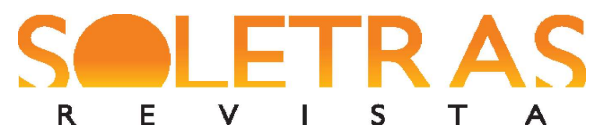

N. 41 - 2021.1 - FLÁVIA SABOYA DA LUZ ROSA

o significado mais amplo de refreamento de uma atividade desenvolve-se a partir do contexto de origem, não mais restrito ao sentido de suspensão da marcha da tropa, mas expandido à cessação de outras práticas para além do cenário militar. Em se tratando da composicionalidade de alto lá, ainda que haja transparência parcial no significado do elemento alto, advindo da permanência das relações biossociais, é possível perceber que não há referência espacial por meio do lá, que constitui uma subparte da expressão dependente sintática e semanticamente da outra subparte, caracterizando-se como afixoide. Comparada à forma do estágio anterior, alto lá é considerada menos composicional, devido à transparência parcial do elemento alto e à vinculação da subparte afixoide. Com base em Rosa (2019), acreditamos que a emergência da unidade sintático-semântica alto lá tenha sido licenciada por analogia à macroconstrução $\left[\mathrm{V}_{\text {indut }} \mathrm{Afix}_{\mathrm{Loc}}\right]_{\mathrm{MD}}{ }^{13}$. Com surgimento de forma nova e estabelecimento do significado mais amplo a partir do original - o que constitui certa permanência semântica -, entendemos ter havido, do primeiro ao segundo estágio, mudança construcional, nas definições de Traugott e Trousdale (2013).

- Contexto crítico

Diewald (2002, 2006) declara que o contexto crítico deflagra o efetivo desencadeamento do processo de construcionalização, é marcado por ambiguidade e que entre as possibilidades de interpretação está o novo significado. Segundo a autora, nesse estágio, surgem novas construções que não podem ser reduzidas a uma combinação de expressões conhecidas sem perda de informação. A partir dessa noção, analisemos o exemplo a seguir:

(3) Era ali o sumptuoso gabinete de leitura e música de D. Ifigénia. Ornavam as paredes dois retratos a corpo inteiro: Calisto Elói com a farda de fidalgo cavaleiro, e Ifigénia trajada de amazona... - Olha o meu marido! - clamou Teodora. - Aquela é a tal mulher? - perguntou à espantada Tomásia. - Aquela é a Sr.a D. Ifigénia. - Vou rasgar aquele diabo! - berrou a morgada, arrastando uma cadeira para trepar. - Isso alto lá, minha senhora! - acudiu irada a despenseira. - V. Ex.a não estraga coisa nenhuma. E, se continua nesse disparate, eu mando chamar o cabo da rua para a pôr lá fora. - Pôrme a mim lá fora! - bradou Teodora. - Sim, minha senhora, que isto não são termos. Nem me parece senhora! Cá em Lisboa acções destas só as praticam as peixeiras. (Corpus do Português: A queda dum anjo, de Camilo Castelo Branco, 1866).

\footnotetext{
13 A construção marcadora discursiva (MD) é constituída por verbos indutores ( $\mathrm{V}_{\text {indut }}$ ) e afixoides de origem locativa (Afix ${ }_{\text {Loc }}$ ) (cf. TEIXEIRA, 2015; ROSA, 2019). Em Rosa (2019), defende-se que, no século XIX, a construcionalização de alto lá ocorreu por meio do melhor encaixe (HUDSON, 2010) com algumas características da macroconstrução $\left[\mathrm{V}_{\text {indut }} \mathrm{Afix} \mathrm{Loc}_{\mathrm{LD}}\right]_{\mathrm{M}}$.
} 


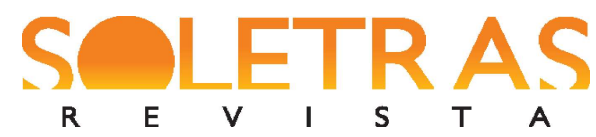

N. 41 - 2021.1 - FLÁVIA SABOYA DA LUZ ROSA

No exemplo (3), o emprego da expressão alto lá apresenta, ao menos, duas possibilidades de interpretação. Na primeira delas, captamos o significado desenvolvido no contexto atípico: interrupção de atividade. O narrador da história explica que, ao anunciar que rasgaria o mencionado retrato, Teodora arrasta uma cadeira para nela subir e concretizar o ato. Logo, o uso de alto lá pela despenseira pode apresentar o sentido de suspender o movimento de sua interlocutora de subir na cadeira para alcançar o retrato e então rasgá-lo. O que permite essa leitura é o conhecimento da conjuntura conversacional, nesse caso específico, a informação dada pelo autor de que Teodora estava "arrastando uma cadeira para trepar". Sob essa ótica, o uso de alto lá estaria relacionado a cessar uma atividade vinculada ao mundo biossocial, conforme foi observado nos contextos anteriores.

Entretanto, é possível realizar uma análise diferente. Uma segunda interpretação fornece a ideia de que o emprego de alto lá pode estar associado não à ação de Teodora, mas ao seu enunciado "Vou rasgar aquele diabo!". Assim, o significado da construção não mais expressaria interrupção de atividade/prática do mundo biossocial, passando a exprimir o refreamento de uma proposição, que antecede a refutação "V. Ex.a não estraga coisa nenhuma. E, se continua nesse disparate, eu mando chamar o cabo da rua para a pôr lá fora". Desse modo, a atuação da microconstrução estaria relacionada ao âmbito discursivo. A anteposição do pronome demonstrativo "isso" à expressão alto lá parece favorecer tal interpretação, por assemelhar-se a características de construções mais cristalizadas como "isso é o que veremos" e afins, em que "isso" aponta para o enunciado anteriormente produzido. No entanto, se ainda há possibilidade de leitura semelhante ao contexto anterior, ou seja, relacionada à interrupção de atividade do mundo biossocial, em que "isso" refere-se ao movimento direcionado à destruição do retrato, então, o contexto em questão não pode ser considerado único, isolado.

Logo, entendemos que o construto em foco pertence a contexto crítico pelos seguintes motivos: observamos haver ambiguidade no uso de "alto lá" em (3), pois o sentido parece se relacionar tanto ao refreamento da ação de arrastar uma cadeira para nela subir e estragar o retrato quanto ao refreamento da afirmação "Vou rasgar aquele diabo!"; além disso, a segunda leitura fornece o novo significado de refreamento-argumentativo da construção, estritamente ligado ao discurso, que será tratado adiante no contexto isolado.

- Contexto isolado 


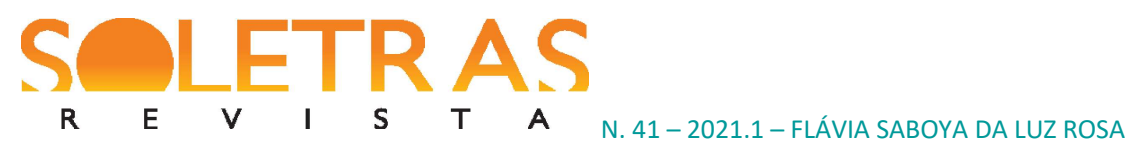

Diewald $(2002,2006)$ afirma que esse contexto mostra a consolidação do processo de mudança em que o novo sentido é isolado, como um sentido separado do mais antigo. De acordo com a pesquisadora, as construções em contextos isolados assemelham-se apenas parcialmente a outras construções existentes e apresentam uma correspondência formaconteúdo única. Analisemos o pertencimento do seguinte construto a esse contexto:

(4) [...] salvou galhardamente a vida das garras de uma onça e é motivo de sobra para que eu lhe seja eternamente agradecida, e creio que também para que o primo não abocanhe e não despreze assim um homem, que não lhe fez mal algum. - Nenhum mal.. eu sei. e também que me importa a mim esse homem. Ou por sim, ou por não, amanhã ou depois, logo que ele possa montar a cavalo, hei de levá-lo para minha casa, porque é nosso hóspede, e meu tio nenhuma obrigação tem de agüentá-lo. - Alto lá, primo! - atalhou Paulina com vivacidade; - menos essa.. temos muito mais obrigação do que o senhor, e havemos de agüentá-lo com muito prazer. Enquanto não sarar de todo, ele é nosso, e não arreda pé daqui. - Isso era bem belo. e a mulada dele que lá fica à toa.. não hei de ser eu que hei de tomar conta dela. (Corpus do Português: Histórias e tradições da província de Minas Gerais, de Bernardo Guimarães, 1872).

No fragmento (4), o emprego de alto lá exprime, de forma isolada (sem ambiguidade), o sentido de refrear a proposição enunciada pelo primo de Paulina: "logo que ele possa montar a cavalo, hei de levá-lo para minha casa, porque é nosso hóspede, e meu tio nenhuma obrigação tem de agüentá-lo". Paulina, então, utiliza a construção refreadora para introduzir a sua posição contrária ao que foi dito "menos essa" e, em seguida, apresentar sua refutação “temos muito mais obrigação do que o senhor, e havemos de agüentá-lo com muito prazer. Enquanto não sarar de todo, ele é nosso, e não arreda pé daqui”.

Nesse exemplo, a construção alto lá mostra-se ainda menos composicional do que nos contextos anteriores, pois a subparte nuclear alto, fortemente vinculada ao afixoide lá, já não expressa referência ao mundo biossocial, integrando uma unidade, em pareamento de forma e conteúdo, que aponta exclusivamente para o âmbito discursivo.

Entendemos que construtos como o apresentado em (4) são empregados em contexto isolado. De fato, conforme declara Diewald (2002, 2006), há semelhança formal desta construção exemplificada com aquelas de contextos anteriores, porém, comparando-se a expressão do contexto fonte com a deste estágio, é possível afirmar que houve pareamento convencional de uma nova forma e de um significado novo a serviço do uso discursivo, isto é, houve construcionalização. 


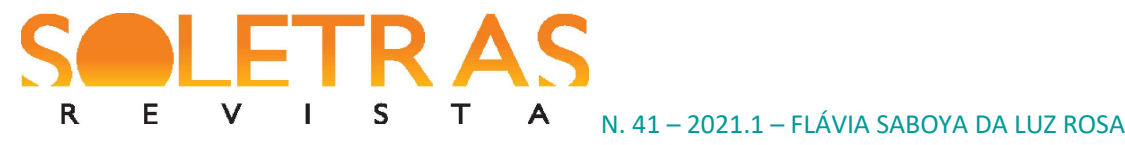

Compartilhamento cognitivo-cultural

No processo de mudança para o uso discursivo, em modo argumentativo de organização discursiva, da frase nominal interjetiva alto, originalmente empregada em cenários de combate, verificamos a atuação do que Lakoff e Johnson (2003) denominam de metáfora conceptual DISCUSSÃO É GUERRA. Constatamos que o uso das expressões alto e alto lá faz parte de uma conceptualização cultural, em que um fenômeno, a discussão, é praticado, compreendido e descrito em termos de outro, a guerra. Segundo Lakoff e Johnson (2003), numa discussão, apesar de não haver batalha física, há uma batalha verbal. No português do Brasil, o termo discussão apresenta, basicamente, duas acepções diferenciadas e metonimicamente relacionadas: debate e bate-boca. O modo argumentativo de organização discursiva está intimamente associado à acepção de debate: "Discussão em que se apresentam argumentos a favor ou contra alguma coisa (um argumento, uma proposta, uma ação etc.), visando a uma conclusão (debates parlamentares/judiciários)" (AULETE, 2019). Por essa razão, associamos a acepção de debate ao termo discussão lógica. A discussão também pode ser permeada por exaltação de ânimos e até mesmo resultar em altercação/bate-boca. Nesse caso, associamos a acepção de bate-boca ao termo discussão irrefletida. Sob um olhar mais específico, com foco na argumentação, constituinte dos debates ou discussões lógicas, constatamos haver paralelismo entre os mecanismos argumentativos e as investidas entre os beligerantes: proposição (ataque), justificação (defesa), refutação (contra-ataque), ponderação (espécie de trégua). A metáfora conceptual DISCUSSÃO É GUERRA, vivenciada em tantas culturas como a nossa, é espelhada na linguagem cotidiana por uma ampla variedade de expressões, como, por exemplo:

- Suas reivindicações são indefensáveis.

- Ele atacou todos os pontos fracos do meu argumento.

- Suas críticas foram certeiras.

- Eu destruí o argumento dele.

- Eu nunca ganhei uma discussão com ele.

- Você discorda? Então, manda bala!

- Se você usar essa estratégia, ele vai acabar com você.

- Ele derrubou todos os meus argumentos.

(LAKOFF; JOHNSON, 2003, p. 5. Tradução nossa). 


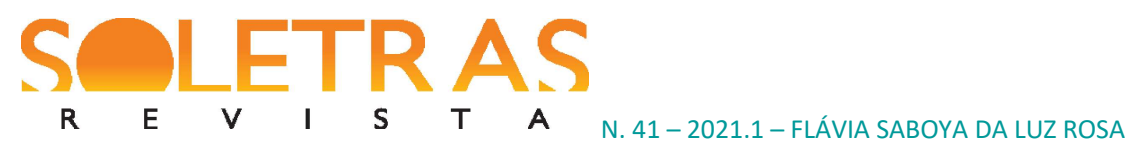

Para os autores, é importante observar que não apenas falamos de discussão em termos de guerra, mas também entendemos que realmente ganhamos ou perdemos discussões; vemos a pessoa com quem estamos discutindo como um oponente; atacamos suas posições e defendemos as nossas; planejamos e usamos estratégias; abandonamos posições indefensáveis e tomamos nova linha de ataque etc. Discussões e guerras são tipos diferentes de eventos discurso verbal interativo e conflito armado - e as ações praticadas são diferentes em cada um deles. No entanto, a primeira é parcialmente compreendida, executada e abordada em termos da segunda, ou seja, o conceito, a atividade e, consequentemente, a linguagem referentes à discussão são metaforicamente estruturados por meio da noção de guerra. Vejamos um exemplo de nosso corpus, cujas expressões são referidas na Figura 1 adiante. As relações metafóricas, metonímicas ou analógicas específicas das expressões em destaque não serão aqui desenvolvidas em prol da observação maior sobre a metáfora conceptual em foco e o englobamento da expressão alto:

(5) - Nego! exclamou formidavelmente o cônego que em sua casa, à sua mesa, punha de alto as suas opiniões. - E nego com os meus autores. Eles aí vão! E deixou-lhe cair em cima, como penedos de autoridade, os nomes venerados de Laboranti, Baldeschi, Merati, Turrino e Pavônio. Amaro afastara a cadeira, pusera-se em atitude de controvérsia, contente de poder, diante de Amélia, "enterrar" o cônego, mestre de teologia moral e um colosso de liturgia prática. - Sustento, exclamou, sustento com Castaldus... - Alto, ladrão, bramiu o cônego. Castaldus é meu! - Castaldus é meu, padre-mestre! E encarniçaram-se, puxando cada um para si o venerável Castaldus e a autoridade da sua facúndia. D. Josefa pulava de gozo na cadeira, murmurando para Amélia com a cara franzida de riso: - Ai, que gostinho vê-los! Ai, que santos! (Corpus do Português: $O$ Crime do Padre Amaro, de Eça de Queirós, 1875).

Expressões linguísticas
•1) "deixou-lhe cair em cima,
como penedos"
•2) "enterrar"
•3) "Alto"
•4) "ladrão"
•5) "encarniçaram-se"
•6) "puxando cada um para
si"

Domínio fonte: guerra
-1) contra-ataque
-2) enterro: consequência da
morte em guerra
-3) interrupção da marcha
-4) Inimigo
•5)encarniçamento
-6) disputa

\section{Domínio alvo: discussão}

-1) refutação

-2) completa desqualificação da proposição, sem possibilidade de réplica

-3) refreamento da alegação

-4) interlocutor

-5) persuasão provocativa

•6) sucessão de justificações

Figura 1: Domínios fonte e alvo da metáfora conceptual DISCUSSÃO É GUERRA aplicados ao exemplo (5)

Fonte: Autoral. 


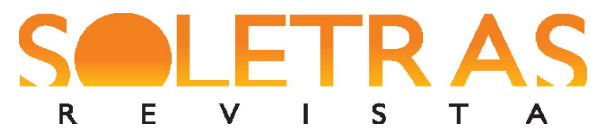

$\mathrm{O}$ uso de alto no exemplo (5) retrata o emprego do que, originalmente, seria o comando de interrupção de marcha da tropa, atividade situada no mundo biossocial. Essa referência, mais concreta, serve, por meio de mecanismos metafóricos, a uma prática mais abstrata, situada no campo discursivo: o refreamento - no exemplo, trata-se de interrupção propriamente dita -, da justificação do locutor. É preciso atentar para o fato de que, ao proferir a palavra de ordem alto, o enunciador não só se vale da linguagem metafórica como também executa uma ação metaforicamente estruturada. Ele apropria-se da autoridade de um comandante para determinar a cessação da alegação alheia, munindo-se de uma espécie de patente habilitada pela detenção e convicção da verdade. Portanto, entendemos que a metáfora conceptual DISCUSSÃO É GUERRA licencia o uso do comando alto, e, por conseguinte, alto lá, no domínio discursivo.

\section{A microconstrução toma lá dá cá}

O estudo da microconstrução toma lá dá cá integra o projeto, ainda em desenvolvimento inicial, intitulado A construção de correlação locativa: movimento contínuo, multiplicidade, modo e mutualidade. $\mathrm{O}$ referido projeto tem como objeto de pesquisa, como o próprio título indica, a construção de correlação locativa, representada por microconstruções tais como "pata aqui, pata acolá", "poça daqui, lama dali”, "concorda aqui, discorda ali", "balança pra lá, balança pra cá”, entre outras. Constituem os principais objetivos desta investigação: i) descrever o funcionamento da construção composta por segmentos correlatos $\left[\mathrm{X}_{1}\left(\text { Prep}_{\text {Loc }}, \mathrm{X}_{2} \text { (Prep)Loc } 2\right]_{\mathrm{Y}}\right.$, em que cada um desses segmentos é formado por subpartes nominais ou verbais $\left(\mathrm{X}_{1}, \mathrm{X}_{2}\right)$ associadas a subpartes adverbiais locativas $\left(\operatorname{Loc}_{1}, \operatorname{Loc}_{2}\right)$, podendo haver inserção facultativa de preposição (Prep) entre as subpartes; ii) verificar a hipótese de que as construções de correlação locativa apresentam conteúdo semânticopragmático $(\mathrm{y})$ relacionado a movimento contínuo de seres ou de partes deles, multiplicidade quantitativa e/ou tipológica de elementos de um grupo, modo ou qualidade com que se realiza uma ação e mutualidade/reciprocidade de ações e/ou intenções entre as entidades envolvidas; iii) mapear, por meio de análise pancrônica, os estágios dos contextos de mudança construcional (DIEWALD, 2002, 2006; ROSA, 2019) e averiguar possíveis integrações paradigmáticas (DIEWALD; SMIRNOVA, 2012). 


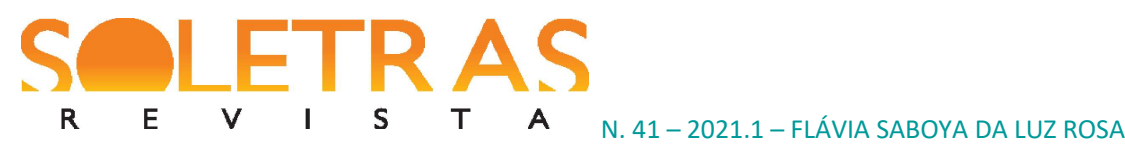

Para atingir o propósito de elaboração do presente artigo, a análise desta seção circunscreve-se ao estudo referente à microconstrução toma lá dá cá, a partir dos resultados obtidos até o estágio atual de desenvolvimento do projeto de pesquisa anteriormente descrito. Embora os dados inicialmente coletados tenham sido produzidos nas últimas duas décadas, e o avanço investigativo rumo aos anos mais longínquos ainda seja uma etapa a ser cumprida em nossa agenda de pesquisa, é possível traçar uma trajetória preliminar de construtos em termos de composicionalidade e analisabilidade ${ }^{14}$. Os primeiros exprimem referência a contextos mais concretos do mundo biossocial, ao passo que os últimos expressam relações mais abstratas. É importante destacar que, mesmo no dado de uso mais concreto a ser exposto a seguir, a expressão toma lá dá cá já apresenta status construcional, isto é, já constitui relação biunívoca de forma e conteúdo, de modo que o somatório do significado de cada subparte não exprime com eficácia a totalidade do conteúdo da construção.

(6) Atual campeão europeu, o Saracens havia acabado de receber a notícia de seu rebaixamento automático na Premiership inglesa e, mesmo assim, seu elenco estrelado encarou o clube de Paris de igual para igual e conquistou uma dramática e crucial vitória por $27 \mathrm{X} 24$, jogando com um homem a menos por vermelho a Skelton. Itoje cravou o primeiro try inglês logo a 1', mas Vakatawa respondeu para os franceses na sequência. O jogo foi um toma lá dá cá de emoção, com Mako Vunipola marcando o segundo try dos Sarries, enquanto Dupichot e outra vez Vakatawa responderam com os tries que colocaram o Racing na frente antes do intervalo. O segundo tempo, no entanto, foi do Saracens, com Itoje marcando novo try e Farrell chutando penal decisivo nos instantes finais. (Disponível em: http://www.portaldorugby.com.br/noticias/saracens-saints-e-ulster-nas-quartas-daheineken-champions-cup. Acesso em: 12 de set. de 2020).

No exemplo (6), o construto toma lá dá cá é empregado para indicar a boa performance de ambas as equipes de rugby, em que as jogadas realizadas de uma contra a outra resulta, de modo eficiente, na marcação de pontos. Observando o entorno linguístico, encontramos algumas expressões que contribuem para o entendimento de que o principal conteúdo semântico do construto é a mutualidade ou reciprocidade:

- "O Saracens $[\ldots]$ encarou o clube de Paris de igual para igual";

14 Bybee (2010) distingue composicionalidade de analisabilidade. A primeira relaciona-se ao grau de previsibilidade do todo com base no significado das partes, a última refere-se à contribuição de cada componente para o conteúdo do todo. Tal entendimento nos permite tratar de subpartes construcionais. É importante destacar que tanto a composicionalidade quanto a analisabilidade são parâmetros gradientes e, portanto, nos referimos a construtos mais ou menos composicionais e/ou analisáveis. 


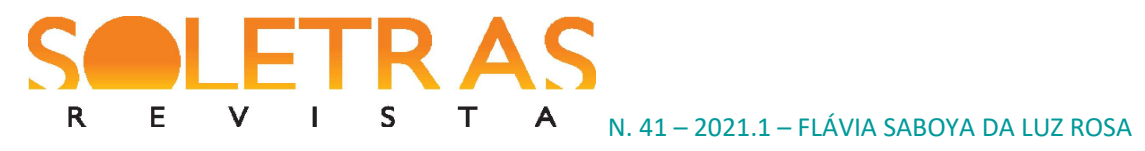

- "Itoje cravou o primeiro try inglês logo a 1', mas Vakatawa respondeu para os franceses na sequência;

- "Mako Vunipola marcando o segundo try dos Sarries, enquanto Dupichot e outra vez Vakatawa responderam com os tries que colocaram o Racing na frente antes do intervalo".

A ênfase na paridade dos times é manifestada ao longo de quase todo o fragmento de texto. Até mesmo a informação inicial do êxito de uma das equipes, "conquistou uma dramática e crucial vitória por 27 X 24”, aponta para a equilíbrio entre os adversários, tendo em vista que, no âmbito esportivo, um jogo dramático corresponde a uma partida difícil de ser vencida, de placar apertado. O relato sobre a equivalência dos times é reformulado apenas na última linha: "O segundo tempo, no entanto, foi do Saracens".

No trecho exemplificado, a mutualidade expressa por meio de toma lá dá cá está relacionada ao desempenho entre adversários de rugby, um esporte de contato físico pleno, portanto, o uso do construto aponta para uma ação concreta de reciprocidade por disputa, explicitada pelas formas verbais toma (= equipe recebe ataque do adversário e leva um ponto) e $d a ́$ (= equipe realiza ataque ao adversário e marca um ponto). Embora o principal conteúdo semântico constatado no emprego do construto toma lá dá cá em (6) seja a mutualidade, também é possível verificar em seu uso a ideia de i) modo, já que qualifica a maneira como o jogo ocorreu: uma disputa acirrada; ii) movimento contínuo, pois as investidas e marcações de pontos de cada equipe são descritas como sequenciais às de seu oponente. Tendo em vista a divisão de campo característica desse esporte e o fato de a jogada de cada clube ocorrer em direção oposta àquela realizada pelo adversário, consideramos que o uso dos advérbios locativos lá e cá ilustram o deslocamento dos atletas de um extremo a outro do gramado. Contudo, não há, de fato, locomoção dos esportistas para o local em que se encontra o enunciador, conforme definição mais básica e original do advérbio locativo cá. Tampouco o conteúdo de ação sequencial está explícito na simples soma de significado de cada subparte da microconstrução, pois é a instanciação, nesse contexto específico, do pareamento formaconteúdo de correlação locativa que promove a leitura de atos que se sucedem, como se houvesse a repetição toma lá dá cá, toma lá dá cá, toma lá dá cá... Por essas razões, o construto em foco não é considerado totalmente composicional, apesar de apresentar maior 


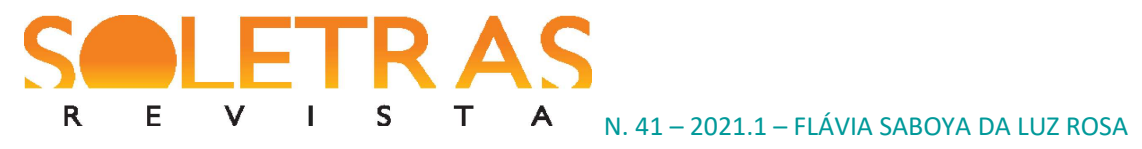

analisabilidade do que os construtos exemplificados adiante; iii) multiplicidade quantitativa, já que a noção de repetição anteriormente apontada caracteriza a abundância de jogadas.

(7) Em sala de aula, Maria presenciou dois fatos: primeiro ela viu que Jamal pegou o lanche de Cristiano. Pouco depois, ela vê Cristiano revidar ao pegar a caneta preferida de Jamal. Maria não relata esses incidentes ao professor, pois, para ela, foi um "tomalá-dá-cá", já que as ações, segundo sua visão, foram iguais.

(Disponível em: https://brainly.com.br/tarefa/17779560. Acesso em: 11 de ago. de 2020).

Em (7), o emprego do construto toma lá dá cá também suscita, primordialmente, a ideia de mutualidade. No trecho narrado, a personagem Maria presencia, entre seus colegas de classe, dois atos socioculturalmente reprováveis e não os relata ao professor, porque "[...] as ações, segundo sua visão, foram iguais". Isto é, em sua opinião, houve um dano que foi desagravado ao ser pago com outro dano. Nesse contexto, apesar de as atitudes atribuídas a Jamal e Cristiano representarem ações concretas (pegar o lanche e pegar a caneta), já não se referem a ações de reciprocidade por disputa (no caso, esportiva) com contato físico, como ocorre no exemplo anterior, e sim de reciprocidade por ação de revide. É possível ainda verificar que o uso do construto em tela exprime o modo como ocorreram as ações, ou seja, qualifica a cena como um ato provocativo e retaliativo. Diferentemente do que foi observado no dado anterior, o emprego de toma lá dá cá no fragmento (7) não expressa a ideia de repetição, referindo-se apenas a uma única ação causadora da reação e uma única ação de revide, consequente da primeira. Por conseguinte, não havendo repetição de atos, não ocorre multiplicidade dos mesmos. No que tange às referências ainda expressas pelos locativos, pode-se verificar que lá e cá não se relacionam diretamente com os locais em que se encontram narrador ou se passa a narrativa, mas com a ideia de direcionamento da ação, que parte de um personagem para atingir o outro e vice-versa. Tal direcionamento pode ser associado à máxima popular, bastante difundida na cultura brasileira, "tudo o que vai volta", expressão relacionada à metáfora conceptual A VIDA É UMA VIAGEM. Sendo assim, constatamos que o uso de toma lá dá cá no trecho (7) é mais abstratizado e menos composicional do que em (6).

O ditado popular "tudo o que vai volta" apresenta basicamente duas implicações: i) Se você pratica o mal, recebe o mal e ii) Se você pratica o bem, recebe o bem. A primeira implicação pôde ser observada por meio da narrativa do exemplo anterior, em que o construto toma lá dá cá foi empregado para expressar ato de mutualidade por revide ou retaliação, ou 


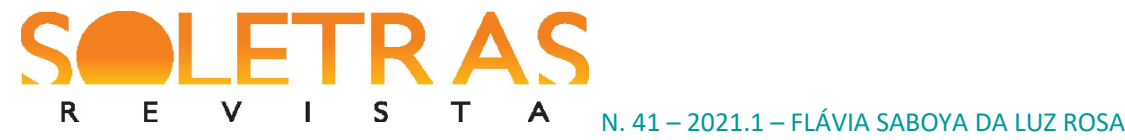

seja, em que se paga o mal com o mal. No contexto do âmbito da política, e muito em voga no discurso midiático contemporâneo para retratar um tipo de conduta do governo do Brasil, a microconstrução toma lá dá cá define mutualidade por meio de favores políticos. Tal uso representa uma curiosa apropriação da segunda implicação supracitada, em que se paga o bem pelo bem. O paradoxo está no fato de a relação benéfica e vantajosa entre os entes envolvidos nessas ações de reciprocidade ser, na maioria dos casos, avaliada como antiética pela sociedade de modo geral. Vejamos um exemplo desse emprego:

(8) A nova política de Jair Bolsonaro parece a velha. Depois de muito assegurar que com ele era diferente, o capitão derramou um caminhão de dinheiro, desviado da educação, para abastecer as emendas parlamentares que garantiram a aprovação da reforma da Previdência na Câmara dos Deputados. Foi um toma-lá-dá-cá no melhor, ou pior, estilo do é dando que se recebe.

(Disponível em: https://www.correiodopovo.com.br/blogs/juremirmachado/aestranha-1\%C3\%B3gica-de-bolsonaro-1.361470. Acesso em: 13 de out. de 2020).

No fragmento (8), o colunista descreve o direcionamento de verbas para as emendas parlamentares por parte do presidente da república, que recebeu como contrapartida dos integrantes do parlamento a aprovação da reforma da previdência na Câmara. Assim como no exemplo anterior, o emprego de toma lá dá cá em (8) expressa ações de reciprocidade, contudo, nesse caso, trata-se de mutualidade por meio de favores, em que um benefício é retribuído por outro benefício. Constatamos que as subpartes locativas da microconstrução analisada, cá e lá, não se referem a espaços físicos, como consta em suas acepções mais básicas, mas, constituindo o pareamento forma-conteúdo da correlação locativa, imprimem a ideia de direcionamento de ações mútuas.

(9) A mais recente edição do Portuguese Brazilian Awards, que aconteceu no Castle Hotel \& Spa, em Nova York, continua rendendo bons frutos para Antonia Fontenelle, que está à frente do ótimo "Na Lata". Um deles é a apresentação do evento no ano que vem. "Obrigada, Marcília Luzbet e Danilo Costa", escreveu no Instagram. Mais que depressa, uma internauta rebateu: "Convite pra tudo agora, né? Deus te proteja". Aí, foi um toma lá, dá cá! "Fui convidada antes da resposta da justiça. Meritocracria, babe". (Disponível em: https://gente.ig.com.br/colunas/marcelo-bandeira/2019-0722/ex-domino-bonitao-klaus-hee-pode-integrar-elenco-de-a-fazenda-11.html. Acesso em: 22 de set. de 2020).

No fragmento de texto (9), o uso de toma lá dá cá exprime, sobretudo, mutualidade por revide discursivo. Em rede social, Antonia Fontenelle agradece aos organizadores do 


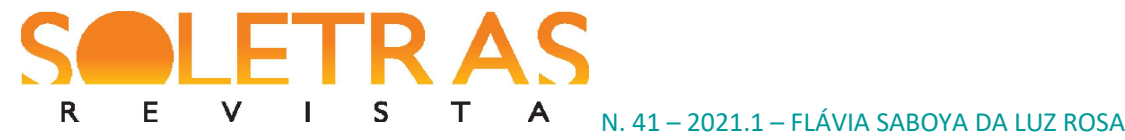

Portuguese Brazilian Awards pelo convite para apresentar o evento do ano seguinte. No entanto, o comentário de uma internauta desagrada a socialite: "Convite pra tudo agora, né? Deus te proteja". Fontenelle, acreditando se tratar de comentário irônico em referência à decisão judicial que a reconhece como uma das herdeiras do diretor Marcos Paulo, rebate: "Fui convidada antes da resposta da justiça. Meritocracria, babe". No emprego do construto em (9), é possível relacionar a subparte toma ao recebimento da proposição discursiva (no caso, ofensiva/irônica) pela ouvinte (Fontenelle) e vincular a subparte dá à produção de resposta (no caso, justificação), no turno de fala seguinte, pela enunciadora (Fontenelle); os locativos lá e cá já não exprimem indicação de lugar concreto, e sim direcionamento de fala aos atores do ato discursivo. Além do conteúdo semântico de mutualidade por discussão, o uso do construto em análise também aponta para o modo, isto é, para a caracterização da discussão, que se dá em configuração argumentativa com uma proposição e uma alegação.

(10) A vida é assim: cada um pensa de uma forma, a gente concorda ali, discorda ali $^{15} \mathrm{e}$ continuamos seguindo, em teoria, juntos. Acho que essa filosofia de vida era mais fácil de ser colocada em prática antes das redes sociais. Independente de política, time de futebol ou religião (coisas que me recuso a opinar), o que eu vi nas últimas semanas foi um toma-lá-dá-cá sem limites. Agressões gratuitas, desavenças entre amigos, desaforos. Uma tristeza virtual, diga-se. Eu sempre gostei muito das redes sociais por elas me aproximarem de amigos distantes. Pensava aqui comigo: poxa, eu em São Paulo, minhas amigas no Rio e em Salvador, minha família longe... Que bom que a gente consegue continuar perto, mesmo que virtualmente. E, pela primeira vez, eu pensei em sair das redes sociais. Triste com o que presenciei. Triste com o que li. (Disponível em: https://dicademae.com/ta-tudo-bugado-mamae/. Acesso em: $28 \mathrm{de}$ set. de 2020).

No exemplo (10), verificamos que as subpartes toma e dá estão respectivamente relacionadas às ideias de recepção e produção de fala ofensiva. As subpartes locativas lá e cá, em emprego metaforizado, indicam o direcionamento de fala entre os atores do ato discursivo, que no fragmento em questão não aparecem de modo explícito. O construto empregado exprime i) mutualidade por discussão agressiva; ii) movimento contínuo, que, nesse contexto, é representado pela alternância incessante de turnos de agressões verbais; iii) multiplicidade quantitativa e qualitativa, evidenciada pelo uso do qualificador "sem limites", que pode apontar tanto para alta produção de falas agressivas, quanto para os tipos dessa produção:

15 Com base em nossos estudos da construção de correlação locativa, $\left[\mathrm{X}_{1}\left(\operatorname{Prep}_{\mathrm{L}} \mathrm{Loc}_{1}, \mathrm{X}_{2}(\operatorname{Prep}) \mathrm{Loc}_{2}\right]_{\mathrm{Y}}, \mathrm{o}\right.$ preenchimento do slot $\operatorname{Loc}_{1}$ é obrigatoriamente diferente do preenchimento do slot $\operatorname{Loc}_{2}$. Sendo assim, pressupomos que o construto pretendido pela autora do texto fosse algo como "concorda aqui, discorda ali" e que a expressão grafada tenha sido fruto de desatenção ou de fenômeno afim. 


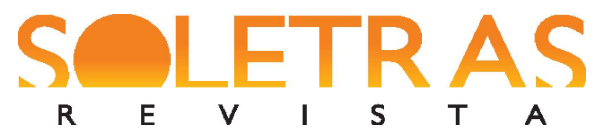

"Agressões gratuitas, desavenças entre amigos, desaforos"; iv) o modo como as relações discursivas ocorreram: com troca de ofensas.

Há basicamente três diferenças entre o uso de toma lá dá cá no exemplo (9) e no exemplo (10). i) No primeiro, estão explicitadas duas personagens envolvidas no ato de fala, ao passo que no segundo há indeterminação dos atores, citados, de modo genérico, como usuários de redes sociais; ii) o construto usado em (9) é empregado para descrever um único "bate e rebate", isto é, uma fala provocativa e uma fala responsiva, já em (10), o construto é usado para definir uma sucessão de falas; iii) Em (9), verificamos a ocorrência de discussão argumentativa, em que se expõe uma proposição e se produz uma alegação para justificação, em (10), são descritas discussões agressivas com trocas de ofensas. No que se refere ao item (iii), Lakoff e Johnson (2003) classificariam o primeiro tipo de discussão racional e o segundo, de irracional. Aqui, conforme mencionado na subseção anterior, preferimos os termos discussão lógica, em que prevalece o raciocínio lógico para formulação dos elementos argumentativos, e discussão irrefletida, dominada pela exaltação de ânimos.

Apesar das diferenças contextuais mencionadas entre os dois últimos exemplos e de seu enquadramento em diferentes tipos de discussão, lógica e irrefletida, ambos os construtos são empregados em âmbito discursivo, distintamente dos exemplos anteriores, cujos construtos são usados para tratar de ações do âmbito biossocial. Verificamos que a direcionalidade espacial mais concreta observada no fragmento (6) por meio do uso dos locativos é metaforizada passando a exercer direcionamento da ação que parte de um personagem para atingir o outro, seja para o bem ou para o mal. No discurso, verifica-se a direcionalidade dos atos de fala, que apontam para cada um dos atores envolvidos. Essa transferência metafórica, que vai da concretude dos apontamentos espaciais para a abstração das relações discursivas, é possível por conta do compartilhamento sociocultural de certos padrões cognitivos, um deles é representado pela metáfora conceptual DISCUSSÃO DEFINE UM CAMINHO. A capacidade que temos de transferir nossas experiências sensório-motoras para o domínio do texto permite pensarmos a discussão em termos da definição de um caminho. A esse respeito, seguem exemplos de expressões metafóricas propostas na obra de Lakoff e Johnson (2003):

- Ele desviou-se da linha de discussão.

- Você está acompanhando minha argumentação? 

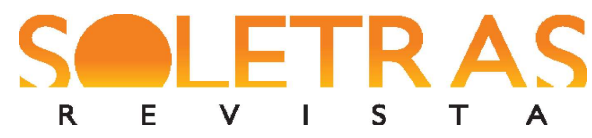

N. 41 - 2021.1 - FLÁVIA SABOYA DA LUZ ROSA

- Partimos na direção errada novamente.

- Estou perdido.

- Você está andando em círculos.

(LAKOFF; JOHNSON, 2003, p. Tradução nossa.)

Tomando algumas expressões empregadas no fragmento (10) como base, podemos traçar relações entre o domínio conceptual do caminho (domínio fonte, mais concreto) e o domínio conceptual da discussão (domínio alvo, mais abstrato), conforme exposto na Figura 2:

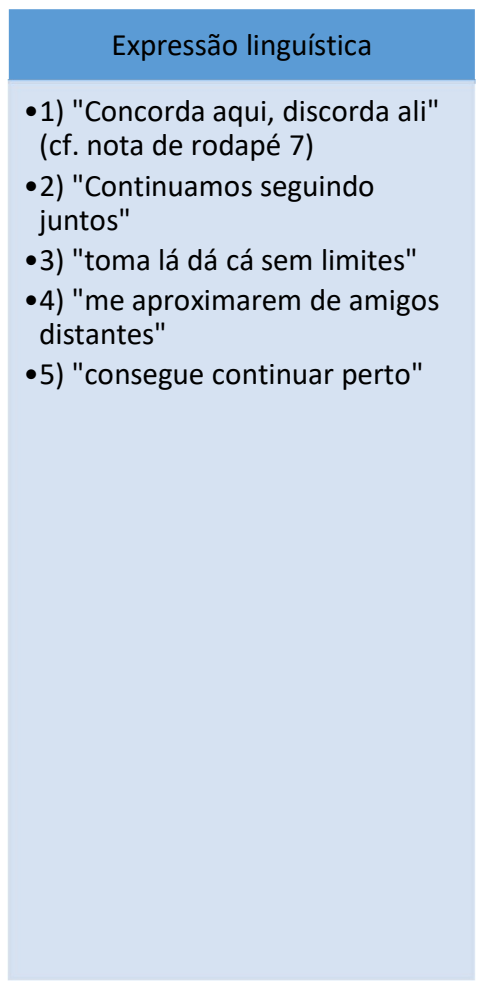

Domínio fonte: caminho
- 1) aqui e ali indicam diferentes
pontos da trajetória,
respectivamente, perto e longe
de quem realiza o percurso.
-2) a expressão indica a
permanência de pessoas
realizando a mesma trajetória
em proximidade.
-3) lá e cá sem limites indica a
repetição incessante da
trajetória que vai de um ponto
longe até um ponto perto de
quem realiza o percurso .
-4) a expressão indica o ato de
percorrer uma trajetória para se
aproximar de pessoas que
estavam distantes do local
inicial de partida do viajante.
-5) a expressão indica a
permanência da pouca distância
de percurso entre uma pessoa e
outra(s).

Domínio alvo: discussão
-1) aqui e ali referem-se a
diferentes objetos de discussão
ou tópicos/temas mais
específicos pertinentes a um
mesmo objeto.
-2) a expressão refere-se à
manutenção das relações
discursivas, apesar das
divergências.
-3) a expressão refere-se à
incessante e grave troca de
ofensas verbais.
-4) a expressão refere-se à
facilidade das interações
discursivas promovida por
plataformas virtuais, apesar da
distância geográfica entre os
internautas.
-5) A expressão refere-se à
continuidade das interações
discursivas por meio de
ambiente virtualapesar da
distância geográfica entre os
internautas.

Figura 2: Domínios fonte e alvo da metáfora conceptual DISCUSSÃO DEFINE UM CAMINHO aplicados ao exemplo (10)

Fonte: autoral

Entendemos que entre os fatores propiciadores das mudanças da microconstrução toma lá dá cá, tais como carga histórica e pressões estruturais, está o compartilhamento sociocultural da metáfora conceptual DISCUSSÃO DEFINE UM CAMINHO. Tal compartilhamento licencia a transferência da direcionalidade mais espacial, como vista no exemplo (6), para a direcionalidade mais abstrata, a partir dos atos de fala discursivos, conforme verificamos nos fragmentos (9) e (10). Sendo assim, a mencionada metáfora 


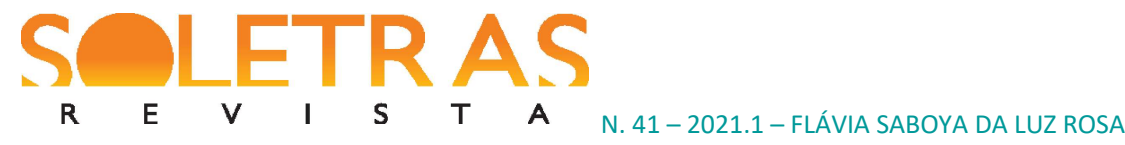

conceptual é compreendida como favorecedora da mudança construcional de toma lá dá cá, ou seja, como fator relevante para ocorrência do fenômeno de mudança em que há permanência da forma e modificação do conteúdo semântico-pragmático.

\section{Considerações finais}

A investigação pancrônica da trajetória de mudança da microconstrução alto lá proporciona um olhar mais holístico sobre fatores propiciadores das mudanças construcionais. Concluímos que os seguintes fatores contribuíram para a integração da microconstrução alto lá ao paradigma dos marcadores discursivos refreador-argumentativos no português brasileiro: i) a conjuntura histórica: nos séculos XVI a XVIII, em que Portugal dedica-se fortemente às guerras, havendo grande difusão da literatura de temática bélica e, consequentemente, dos termos a ela intrínsecos; ii) as neoanálises por meio de micropassos ao longo dos contextos de mudanças; iii) a analogização com características formais e de conteúdo da família $\left[\mathrm{V}_{\text {indut }} \mathrm{Afix} \mathrm{x}_{\mathrm{Loc}}\right]_{\mathrm{MD}}$ (cf. ROSA, 2019); iv) o compartilhamento sociocultural da metáfora conceptual DISCUSSÃO É GUERRA.

Por meio da análise de dados sobre a microconstrução toma lá, dá cá, concluímos que o surgimento de conteúdos semânticos mais abstratos, em relação à semântica espacial mais básica, associa-se a conceptualizações socioculturalmente compartilhadas, como a metáfora conceptual DISCUSSÃO DEFINE UM CAMINHO (LAKOFF; JOHNSON, 2003). É importante registrar que a investigação da microconstrução toma lá dá cá, assim como das demais instanciações da construção de correlação locativa, encontra-se ainda em estágio embrionário.

Assim, acreditamos contribuir para a área da Linguística Cognitivo-Funcional ou LFCU, propondo a comensurabilidade da abordagem construcionalista, sobretudo baseada em Traugott e Trousdale (2013), com a teoria da metáfora conceptual, fundamentada em Lakoff e Johnson (2003).

Em continuidade aos estudos aqui apresentados, incluímos em nossa agenda de pesquisa i) a compatibilização das conceptualizações metafóricas aqui apresentadas, tendo em vista a coerência e a existência de implicações compartilhadas entre essas metáforas, possibilitando a justaposição das mesmas e ii) o estudo pancrônico de determinadas 


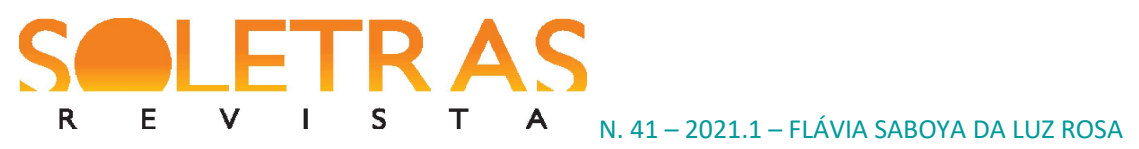

expressões linguísticas metafóricas para verificar se é possível flagrar, ao longo dos séculos, os níveis de compartilhamento sociocultural de alguns padrões cognitivos.

\section{Referências}

BEBIANO, Rui. Sobre a prática e a ideia de guerra em Portugal (séculos XVI a XVIII). Janus, ano 1999-2000.

BLUTEAU, R. Vocabulário portuguez \& latino. Lisboa: Officina de Pascoal da Sylva, 1728.

BOOIJ, Geert Evert. Morphology in Construction Grammar. In: HOFFMANN, T.; TROUSDALE, G. (Ed.). The Oxford Handbook of Construction Grammar. Oxford: University Press, p. 255-273, 2013.

BYBEE, Joan. Language, Usage and Cognition. Cambridge: Cambridge University Press, 2010 .

CROFT, William. Radical Construction Grammar: Syntactic Theory in Typological Perspective. Oxford: Oxford University Press, 2001.

CUNHA, Antônio Geraldo da. Dicionário etimológico da língua portuguesa. Rio de Janeiro: Nova Fronteira, 1997.

DIEWALD, Gabriele. A model for relevant types of contexts in grammaticalization. In: DIEWALD, Gabriele; WISCHER, Ilse (Ed.). New reflexions on grammaticalization. Amsterdam: John Benjamins, 2002.

Context types in grammaticalization as constructions. In: Special Volume 1: Constructions all over - case studies and theoretical implications. 2006. Disponível em: $<$ http:www.constructions-online.de/articles/specvol1/>. Acesso em: 13 de set. de 2020.

; SMIRNOVA, Elena. Paradigmatic integration: the fourth stage in an expanded grammaticalization scenario. In: Grammaticalization and Language Change. New reflections, Davidse, Kristin, Tine Breban, Lieselotte Brems and Tanja Mortelmans (Ed.). [SLCS 130]. Amsterdam: Benjamins, 111-133, 2012.

GIBBS, Raymond W. Jr. Psycholinguistic studies on the conceptual basis of idiomaticity. Cognitive Linguistics, 1990. p. 417-462.

GOLDBERG, Adele. Constructions at Work: The Nature of Generalization in Language. Oxford: Oxford University Press, 2006.

HUDSON, Richard. An Introduction to Word Grammar. Cambridge: Cambridge University Press, 2010. 


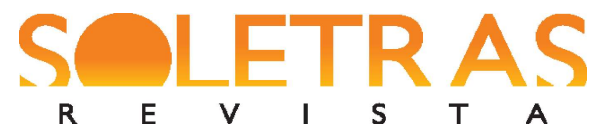

N. 41 - 2021.1 - FLÁVIA SABOYA DA LUZ ROSA

LAKOFF, George. Conceptual metaphor: the contemporary theory of metaphor. In: GEERAERTS, Dirk. Cognitive Linguistics: basic readings. Berlim: 2006, p. 185-238 2003.

; JOHNSON, Mark. Metaphors we live by. Chicago: The University of Chicago Press,

LAKOFF, George; TURNER, Mark. More than cool reason: a field guide to poetic metaphor. Chicago: The University of Chicago Press, 1989.

LANGACKER, Ronald W. Cognitive Grammar: A Basic Introduction. New York: Oxford University Press, 2008.

MARTELOTTA, Mário Eduardo; ALONSO, Karen Sampaio. Funcionalismo, cognitivismo e a dinamicidade da língua. In: SOUZA, Edson Rosa de. (Org.). Funcionalismo linguístico: novas tendências teóricas. São Paulo: Contexto, p. 87-106, 2012.

NASCENTES, Antenor. Dicionário etimológico da língua portuguesa. Rio de Janeiro: Gráfica jornal do comércio 1955.

OLIVEIRA, Mariangela Rios de; ARENA, Ana Beatriz. O viés funcional do pareamento simbólico função $<>$ forma na abordagem construcional da gramática. Soletras, Rio de Janeiro, n. 37, p. 30-58, jan-jun. 2019.

REDDY, Michael J. The conduit metaphor. In: ORTONY, A. Metaphor and Thought. Cambridge: Cambridge University Press, 1993, p.284-324.

ROSA, F. S. L. A mesoconstrução marcadora discursiva refreador-argumentativa: uma análise cognitivo-funcional. 216 fls. Tese (Doutorado em Estudos de Linguagem) Instituto de Letras, Universidade Federal Fluminense, Niterói: RJ, 2019.

SWEETSER, E. From etymology to pragmatics: metaphorical and cultural aspects of semantic structure. Cambridge: Cambridge University Press, 1990.

TEIXEIRA, Ana Cláudia Machado. A construção verbal marcadora discursiva VLocMD: uma análise centrada no uso. 2015. Tese (Doutorado em Estudos de Linguagem) - Instituto de Letras, Universidade Federal Fluminense, Niterói, 2015.

TOMASELLO, Michael. Introduction: a cognitive-functional perspective on language structure. In: TOMASELLO, Michael. (Ed.). The new psychology of language: cognitive and functional approaches to language structure. New Jersey: LEA, 1998, p. 7-23.

Constructing a language: a usage-based theory of language acquisition. Cambridge, MA: Harvard University Press, 2003.

TRAUGOTT, Elizabeth-Closs. Grammaticalization, constructions and the incremental development of language: Suggestions from the development of degree modifiers in English. In Regine Eckardt, Gerhard Jäger, and Tonjes Veenstra, eds., Variation, Selection, 


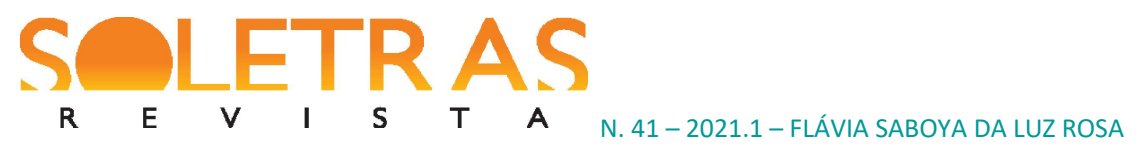

Development--Probing the Evolutionary Model of Language Change. Berlin/New York: Mouton de Gruyter, 2008. p. 219-250.

; TROUSDALE, Graeme. Constructionalization and constructional changes. Oxford: Oxford University Press, 2013.

VEREZA, Solange. Trajetórias da metáfora: retórica, pensamento e discurso. In: VEREZA, Solange (Org.). Sob a ótica da metáfora: tempo, conhecimento e guerra. Niterói: Editora da UFF, 2012.

\title{
The conceptual metaphor as a relevant factor for constructional changes: A view of alto lá and toma lá dá cá micro-constructions
}

\begin{abstract}
The objective of the present paper is to trace relations between two conceptual metaphors recognized in cognitive studies, ARGUMENT IS WAR and ARGUMENT DEFINES A PATH, with the processes that result in the construction change of alto lá and toma lá dá cá micro-constructions. The research is grounded in the Cognitive-Functional Linguistics (TOMASELLO, 1998) or UsageBased Functional Linguistics (adapted from BYBEE, 2010). This work is based, above all, on the constructionalist approach of Traugott and Trousdale (2013), in compatibility with the studies on conceptual metaphor by Lakoff and Johnson (2003). For panchronic investigation of alto lá (ROSA, 2019) we used Corpus do Português and Corpus Tycho Brahe (from $13^{\text {th }}$ to $20^{\text {th }}$ centuries), Diário do Congresso Nacional $\left(20^{\text {th }}\right.$ and $21^{\text {st }}$ centuries) and contemporary publications from the Web. For synchronic study of toma lá dá cá (part of an early stage project) texts from 2000 to 2020 were collected using advanced Google search. Through contextual change analysis of micro-constructions in focus, we verify the emergence of new semantic content associated with socioculturally shared conceptualizations. We conclude that the conceptual metaphor can be an important part, along with historical and structural factors, in the processes of change and establishment of linguistic constructions.
\end{abstract}

Keywords: Conceptual metaphor. Constructional change. Construction. Functionalism. Cognitivism.

Recebido em: 21 de novembro de 2020.

Aceito em: 14 de dezembro de 2020. 